NASA/TM—2009-215495

\title{
Clogging of Joule-Thomson Devices in Liquid Hydrogen Handling
}

John M. Jurns

QSS Group Inc., Cleveland, Ohio

John D. Lekki

Glenn Research Center, Cleveland, Ohio 


\section{NASA STI Program . . . in Profile}

Since its founding, NASA has been dedicated to the advancement of aeronautics and space science. The NASA Scientific and Technical Information (STI) program plays a key part in helping NASA maintain this important role.

The NASA STI Program operates under the auspices of the Agency Chief Information Officer. It collects, organizes, provides for archiving, and disseminates NASA's STI. The NASA STI program provides access to the NASA Aeronautics and Space Database and its public interface, the NASA Technical Reports Server, thus providing one of the largest collections of aeronautical and space science STI in the world. Results are published in both non-NASA channels and by NASA in the NASA STI Report Series, which includes the following report types:

- TECHNICAL PUBLICATION. Reports of completed research or a major significant phase of research that present the results of NASA programs and include extensive data or theoretical analysis. Includes compilations of significant scientific and technical data and information deemed to be of continuing reference value. NASA counterpart of peer-reviewed formal professional papers but has less stringent limitations on manuscript length and extent of graphic presentations.

- TECHNICAL MEMORANDUM. Scientific and technical findings that are preliminary or of specialized interest, e.g., quick release reports, working papers, and bibliographies that contain minimal annotation. Does not contain extensive analysis.

- CONTRACTOR REPORT. Scientific and technical findings by NASA-sponsored contractors and grantees.

- CONFERENCE PUBLICATION. Collected papers from scientific and technical conferences, symposia, seminars, or other meetings sponsored or cosponsored by NASA.

- SPECIAL PUBLICATION. Scientific, technical, or historical information from NASA programs, projects, and missions, often concerned with subjects having substantial public interest.

- TECHNICAL TRANSLATION. Englishlanguage translations of foreign scientific and technical material pertinent to NASA's mission.

Specialized services also include creating custom thesauri, building customized databases, organizing and publishing research results.

For more information about the NASA STI program, see the following:

- Access the NASA STI program home page at http://www.sti.nasa.gov

- E-mail your question via the Internet to help@ sti.nasa.gov

- Fax your question to the NASA STI Help Desk at 301-621-0134

- Telephone the NASA STI Help Desk at 301-621-0390

- Write to: NASA Center for AeroSpace Information (CASI) 7115 Standard Drive Hanover, MD 21076-1320 


\section{Clogging of Joule-Thomson Devices in Liquid Hydrogen Handling}

John M. Jurns

QSS Group Inc., Cleveland, Ohio

John D. Lekki

Glenn Research Center, Cleveland, Ohio

Prepared for the

42nd Joint Propulsion Conference and Exhibit

cosponsored by the AIAA, ASME, SAE, and ASEE

Sacramento, California, July 9-12, 2006

Prepared under Contract NAS3-00145

National Aeronautics and

Space Administration

Glenn Research Center

Cleveland, Ohio 44135 
This report contains preliminary findings, subject to revision as analysis proceeds.

Trade names and trademarks are used in this report for identification only. Their usage does not constitute an official endorsement, either expressed or implied, by the National Aeronautics and Space Administration.

Level of Review: This material has been technically reviewed by technical management.

Available from

NASA Center for Aerospace Information 7115 Standard Drive

Hanover, MD 21076-1320
National Technical Information Service 5285 Port Royal Road Springfield, VA 22161

Available electronically at http://gltrs.grc.nasa.gov 


\title{
Clogging of Joule-Thomson Devices in Liquid Hydrogen Handling
}

\author{
John M. Jurns \\ QSS Group Inc. \\ Cleveland, Ohio 44135 \\ John D. Lekki \\ National Aeronautics and Space Administration \\ Glenn Research Center \\ Cleveland, Ohio 44135
}

\begin{abstract}
Experiments conducted at the NASA Glenn Research Center indicate that Joule-Thomson devices become clogged when transferring liquid hydrogen $\left(\mathrm{LH}_{2}\right)$, operating at a temperature range from 20.5 to $24.4 \mathrm{~K}$. Blockage does not exist under all test conditions but is found to be sensitive to the inlet temperature of the $\mathrm{LH}_{2}$. At a subcooled inlet temperature of $20.5 \mathrm{~K}$ blockage consistently appears but is dissipated when the fluid temperature is raised above $24.5 \mathrm{~K}$. Clogging steadily reduced flow rate through the orifices, eventually resulting in complete blockage. This tendency poses a threat to spacecraft cryogenic propulsion systems that would utilize passive thermal control systems. We propose that this clogging is due to trace amounts of neon in the regular $\mathrm{LH}_{2}$ supply. Neon freezes at $24.5 \mathrm{~K}$ at one atmosphere pressure. It is postulated that between 20.5 and $24.5 \mathrm{~K}$, neon remains in a meta-stable, supercooled liquid state. When impacting the face of an orifice, liquid neon droplets solidify and accumulate, blocking flow over time. The purpose of this test program was to definitively quantify the phenomena experimentally by obtaining direct visual evidence of orifice clogging by accretion from neon contaminates in the $\mathrm{LH}_{2}$ flow stream, utilizing state of the art imaging technology. Tests were conducted with $\mathrm{LH}_{2}$ flowing in the temperature range of 20.5 to $24.4 \mathrm{~K}$. Additional imaging was also done at $\mathrm{LH}_{2}$ temperatures with no flow to verify clear view through the orifice.
\end{abstract}

\section{Introduction}

Previous experimental investigations (Refs. 1 and 2) conducted by the NASA Glenn Research Center Propellant Systems Technology Branch have indicated that:

(1) Joule-Thomson devices, such as the Visco Jet (The Lee Company) and straight orifices, became clogged when transferring $\mathrm{LH}_{2}$, operating at a temperature range from 20.5 to $24.4 \mathrm{~K}$.

(2) No clogging was detected above or below this temperature range.

(3) Clogging steadily and significantly reduces flow rate through the orifices, eventually resulting in complete blockage of the orifice.

This clogging poses a realistic threat to spacecraft propulsion systems that would utilize passive thermal control systems.

We propose that this clogging is due to a trace amount of neon that exists in the regular $\mathrm{LH}_{2}$ supply. It has been further proposed that at temperatures between 20.5 and $24.4 \mathrm{~K}$, neon exists in a metastable, super-cooled liquid state. When impacted on the face of an orifice, the neon solidifies and accumulates on the wall. In time, flow blockage occurs from accretion of solid neon on the orifice. 


\section{Test Program}

\section{Overview}

In 1992, it was noted during flow versus pressure drop tests of $\mathrm{LH}_{2}$ through a Visco-Jet JouleThomson device that flow decreased over time under certain test conditions. A test program was carried out at the NASA Lewis Research Center to determine the cause of this phenomenon. We proposed that neon in the $\mathrm{LH}_{2}$ supply was causing the clogging. Evidence for this theory was supported by the fact that after flow decreased, the flow could be re-established at the original levels by warming the Visco-Jet up to 33.5 to $36.1 \mathrm{~K}$. Raising the temperature possibly caused the neon to melt, allowing flow to be reestablished. Also, a $10 \mu \mathrm{m}$ filter was installed in the inlet line to the Visco-Jet, with no effect (i.e., - the Visco-Jet still clogged). Additional tests were done in which the $\mathrm{LH}_{2}$ temperature was lowered by evacuating the dewar. It was thought that by doing this, the neon would precipitate out. The dewar was then pressurized with helium gas, and the sub-cooled $\mathrm{LH}_{2}$ expelled through the $10 \mu \mathrm{m}$ filter out the Visco-Jet, resulting in 4 to $6 \mathrm{hr}$ operation at a constant flow rate.

The clogging phenomenon has been experimentally verified. The neon contamination theory, although highly plausible, is to this date unconfirmed, because there is no direct evidence of contaminates in the flow stream. The goal of the test program described in this paper was to repeat the tests conducted in 1992 using single orifices with the same flow characteristics as the original Visco-Jet Joule-Thomson devices. In addition, imaging equipment was used to obtain direct visual evidence of the neon clogging by imaging the orifice as $\mathrm{LH}_{2}$ flows through it.

These tests were conducted in 2002 at the Cryogenic Components Lab test cell 7 (CCL-7) of the NASA Glenn Research Center. Tests were performed in September and October of 2002. The test facility is described later in this paper.

\section{Test Objectives}

The objective of these tests was to obtain direct visual evidence of clogging of an orifice by accretion from neon contaminates in the $\mathrm{LH}_{2}$ flow stream, utilizing state of the art imaging technology. We designed an imaging system to look directly into the face of an orifice and record images of the filling of the orifice over time from the accreting objects. This should occur in the temperature range of 20.5 to $24.5 \mathrm{~K}$. We performed additional imaging at temperatures below $20.5 \mathrm{~K}$ and above $24.5 \mathrm{~K}$ in an attempt to verify clear flow through the orifice.

\section{Operating Parameters}

Liquid Hydrogen conditions

(1) Inlet Pressure to orifice-103.4 to $310.3 \mathrm{kPa}$

(2) Pressure drop across orifice- $172.4 \mathrm{kPa}$ maximum

(3) Temperature- 20.5 to $24.5 \mathrm{~K}$

(4) Flow rate -0 to 50 standard liters per minute (slpm)

\section{Test Facility}

CCL-7 is a multipurpose test facility at NASA GRC used to safely, efficiently and economically perform small scale screening tests to verify components and processes in a liquid hydrogen environment (Ref. 3). Test facility capabilities are listed in Table 1. 
TABLE 1.-CCL-7 TEST FACILITY CAPABILITIES

\begin{tabular}{|l|l|}
\hline \multicolumn{2}{|c|}{ Fluid/Thermal systems } \\
\hline Test fluids & $\mathrm{LH}_{2}$ or $\mathrm{LN}_{2}$ \\
\hline Research dewar capacities & 0.326 and $0.164 \mathrm{~m}^{3}$ \\
\hline Facility fluid capacities & $945 \mathrm{~L} \mathrm{LH}_{2}$ \\
\hline & $1,890 \mathrm{~L} \mathrm{LN}_{2}$ \\
\hline Maximum flow rates & 2.3 to $45.4 \mathrm{~kg} / \mathrm{hr} \mathrm{LH}$ \\
\hline & 27.2 to $544.3 \mathrm{~kg} / \mathrm{hr} \mathrm{LN}_{2}$ \\
\hline Pressurants & $\mathrm{GH}_{2}, \mathrm{GHe}, \mathrm{GN}$ \\
\hline Operating pressures & 14 to $379 \mathrm{kPa}$ \\
\hline \multicolumn{2}{|c|}{ Data system } \\
\hline PC based data acquisition system & $\begin{array}{l}256 \text { data channels, LabVIEW } \\
\text { (National Instruments) data } \\
\text { acquisition program. }\end{array}$ \\
\hline
\end{tabular}

The $0.326 \mathrm{~m}^{3}$ research dewar was used for these tests. The inner vessel of this vacuum jacketed dewar is $55.9 \mathrm{~cm}$ diameter, and approximately $76.2 \mathrm{~cm}$ deep. The top of the dewar is fitted with a flat flange lid from which liquid and vent process lines project to deliver $\mathrm{LH}_{2}$ and pressurant gasses. The lid has a short cylindrical section with an inverted dome which is also evacuated and insulated with multilayer insulation to minimize heat transmission through the lid. With this arrangement, heat leak into the test dewar is approximately $20.5 \mathrm{~W} . \mathrm{LH}_{2}$ is fed to the dewar via vacuum insulated piping. The dewar can be vented to atmosphere, or vented to an air ejector which can reduce dewar pressure to approximately $14 \mathrm{kPa}$. Pressure in the dewar can be automatically set and maintained by use of a vent valve operated by a PID controller. Vented gas is warmed through heat exchanger coils before being vented through the rest of the pressure control system. Figure 1 shows a simplified schematic of the research dewar and associated piping and controls.

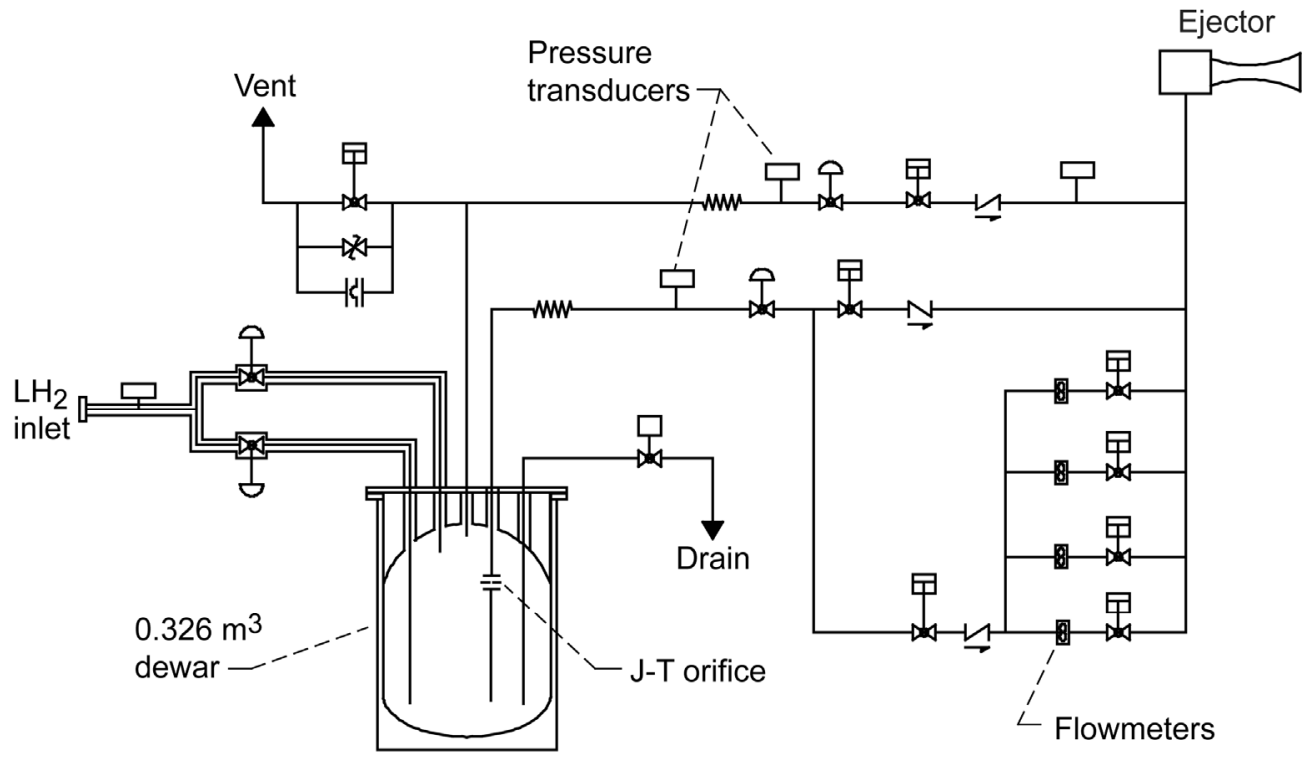

Figure 1._CCL-7 Simplified Piping Schematic Diagram. 


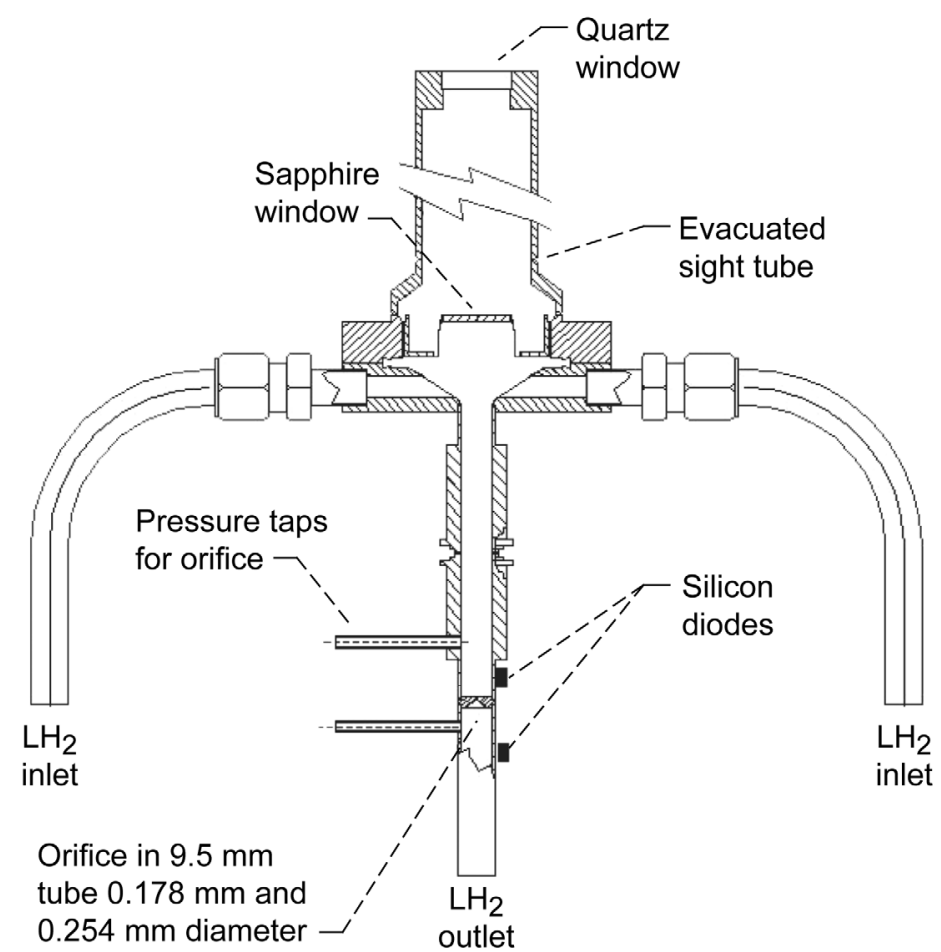

Figure 2.-Details of Orifice and Sight Glass Assembly.

\section{Test Article}

The test article consists of a small square edged orifice welded into a $9.5 \mathrm{~mm}$ diameter stainless steel tube. There are pressure taps upstream and downstream of the orifice. The orifice is viewed through a vacuum insulated sight tube that extends from outside the dewar and attaches to the orifice. Two orifices with diameters of 0.178 or $0.254 \mathrm{~mm}$ were built for this test. Figure 2 shows details of the test article.

\section{Instrumentation}

Temperature sensors are positioned throughout the test rig, on selected fluid lines and components. Temperatures are measured with silicon diodes. Within the research dewar is an instrument tree with silicon diodes attached at discreet heights from 0.5 to 80 percent liquid level. These diodes can be used both to measure the temperature of the contents to within $\pm 0.1 \mathrm{~K}$, and also as point level sensors to determine liquid level to within \pm 0.5 percent. Silicon diodes are also attached to the tubing upstream and downstream of the orifice to monitor $\mathrm{LH}_{2}$ temperature. Strain gauge pressure transducers measure dewar ullage pressure, orifice inlet pressure and differential pressure across the orifice. The flow through the orifice passes through a heat exchanger before being measured using Hastings mass flow meters. The facility has a bank of flow meters allowing measurement of mass flow rates from 0 to 400 slpm.

\section{Data Acquisition}

The facility data acquisition system consists of a multiplexer that digitizes incoming data signals and sends them to a PC based data acquisition program written for the CCL-7 facility. Nominally 96 channels of data are collected and displayed on the PC monitor. Data is acquired at user selected rates from 4 scans per second to one scan per minute and written to a spreadsheet file. 
We acquired images using a digital camera with a telescopic lens to view the orifice. The face of the orifice was approximately $35.6 \mathrm{~cm}$ from the camera lens. The orifice was lit using a LED ring of lights located at the top of the sight tube. Imaging system details are shown in Table 2.

\section{TABLE 2.-IMAGING EQUIPMENT}

\begin{tabular}{|l|l|}
\hline \multicolumn{1}{|c|}{ Component } & \multicolumn{1}{c|}{ Specification } \\
\hline $\begin{array}{l}\text { Nikon model SLR D1 } \\
\text { digital camera }\end{array}$ & $\begin{array}{l}\text { 2.74 megapixel (2012 by 1324 pixel) } \\
\text { resolution CCD }\end{array}$ \\
\hline $\begin{array}{l}\text { Infinity model K2 } \\
\text { microscope lens }\end{array}$ & $\begin{array}{l}\text { Long distance microscope lens, 315 mm } \\
\text { working length, 4 times magnification }\end{array}$ \\
\hline Light source & LED ring, white light, fabricated in-house \\
\hline
\end{tabular}

We controlled the camera using a laptop computer utilizing a proprietary Nikon software package. The laptop was located in the test cell, and was operated remotely from a control room approximately $90 \mathrm{~m}$ away using a remote PC interface. Components located in the test cell were enclosed in a sealed purged cabinet. A schematic of the camera set up is shown in Figure 3.

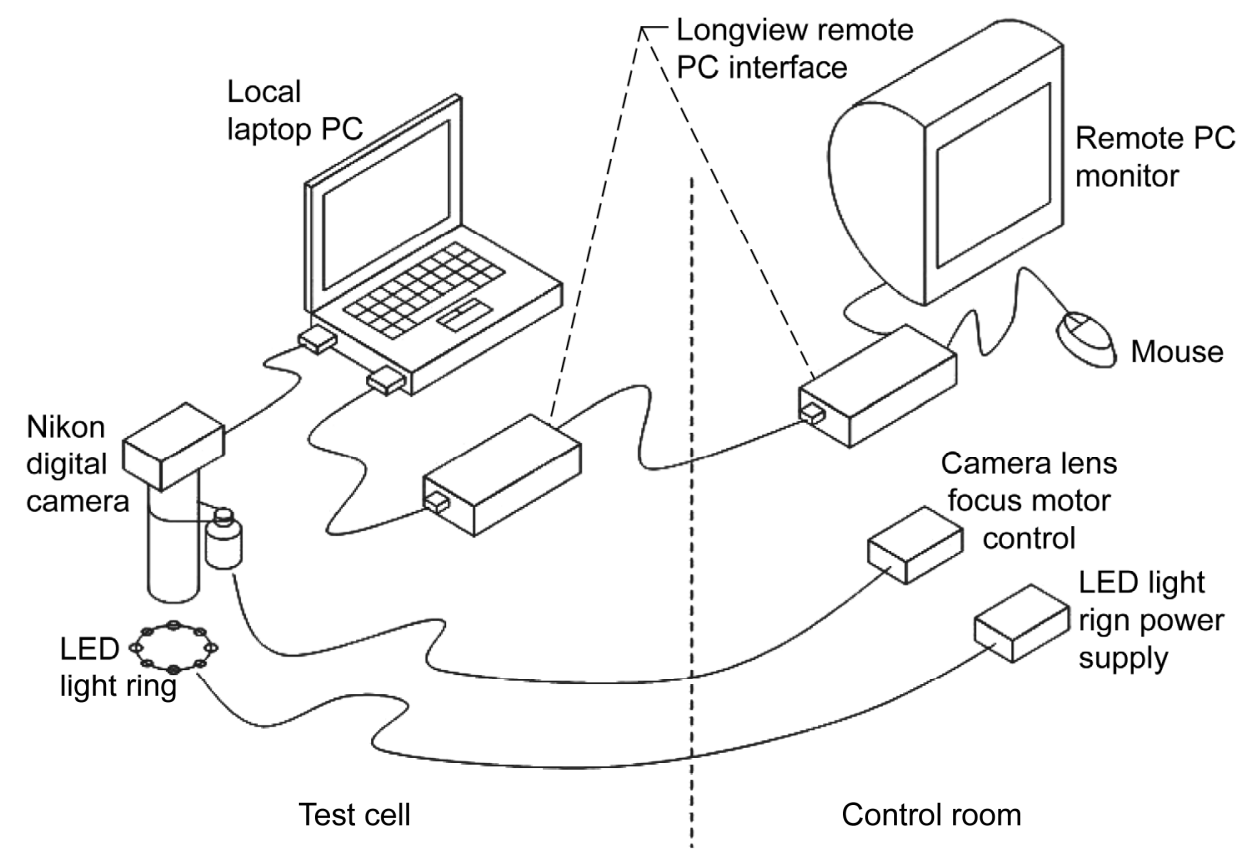

Figure 3.-Nikon Camera Control System Schematic. 


\section{Test Procedure}

Prior to filling the dewar with $\mathrm{LH}_{2}$, we turned on the LED light ring, and focused the camera on the orifice. The dewar was purged and filled with $\mathrm{LH}_{2}$, initially about 50 percent full. The $\mathrm{LH}_{2}$ was conditioned to a saturation pressure and temperature as per the test matrix. This was done by either reducing pressure in the dewar to cool the $\mathrm{LH}_{2}$, or bubbling warm hydrogen gas into the $\mathrm{LH}_{2}$ to raise its temperature. Once test conditions were established, we took additional pictures of the orifice to verify it was still in focus. We established and monitored flow through the orifice. Inlet and outlet temperatures were noted to determine when liquid was flowing through the orifice, and photographs taken throughout the test run. At completion of the test run, we took a final picture of the orifice to verify that it was still in focus. Fluid temperatures, pressures and flow rate were all recorded. Data were typically recorded at a rate of one scan per second. Table 3 summarizes the test runs.

TABLE 3.-SUMMARY OF TESTING

\begin{tabular}{|c|c|c|c|c|c|c|c|}
\hline Data file & $\begin{array}{c}\text { Orifice } \\
\text { diameter }\end{array}$ & $\begin{array}{c}\text { Dewar } \\
\text { press }\end{array}$ & $\begin{array}{c}\text { Bulk } \mathrm{LH}_{2} \\
\text { temp }\end{array}$ & $\begin{array}{c}\text { Orifice inlet } \\
\text { temp }\end{array}$ & $\begin{array}{c}\text { Orifice outlet } \\
\text { temp }\end{array}$ & Initial flow & Time to clog \\
\hline & $\mathrm{mm}$ & $\mathrm{kPa}$ & $\operatorname{deg} \mathrm{K}$ & $\operatorname{deg} \mathrm{K}$ & $\operatorname{deg~K}$ & slpm & minute \\
\hline C702270 & 0.178 & 203.4 & 22.1 & 23.3 & 21.7 & 9.5 & 15 \\
\hline C702277 & 0.254 & 217.2 & 23.1 & 23.3 & 19.4 & $15 ?$ & 22 \\
\hline C702282 & 0.254 & 227.5 & 22.5 & 25 & 19.4 & 37 & 20 \\
\hline C702283 & 0.254 & 227.5 & 22.1 & 25.6 & 20 & $35 ?$ & 15 \\
\hline C702283 & 0.254 & 211.7 & 22.3 & 30 & 22.2 & 14 & 10 \\
\hline
\end{tabular}

\section{Test Results and Discussion}

Initial test runs were unsuccessful in establishing liquid flow at the orifice due to low flow rate, heat conduction through the wall of the sight tube and the fact that the orifice was initially located in the ullage of the dewar. This resulted in the hydrogen vaporizing before it reached the orifice. Heat conduction and hydrogen vaporization problems were corrected by increasing the liquid level in the dewar until it covered the orifice and the end of the sight glass assembly.

Data taken in 1992 and 2002 is shown in Table 4. For both the larger and smaller diameter orifices, the flowrate was lower in 2002 than in 1992. We initially speculated that the orifices were fabricated smaller than design; however, a post test inspection and water calibration of the orifice indicated that the orifice diameter was actually indeed as designed. To date, the reason for this discrepancy has not been resolved. However, orifice inlet temperatures look to be slightly higher than the saturated liquid temperature. Decreased flow rates may be due to cavitation of the liquid hydrogen as it passes through the orifice or two phase flow at the inlet of the orifice. This is discussed in following paragraphs.

TABLE 4.-TEST FLOW RATES AND TEMPERATURES

\begin{tabular}{|l|c|c|c|c|c|}
\hline \multicolumn{2}{|c|}{} & \multicolumn{2}{|c|}{$0.178 \mathrm{~mm}$ orifice } & \multicolumn{2}{c|}{$0.254 \mathrm{~mm}$ orifice } \\
\cline { 3 - 6 } \multicolumn{2}{l|}{} & 1992 & 2002 & $1992 *$ & 2002 \\
\hline Observed flow rate & $(\mathrm{slpm})$ & 45 & 10 & 60 & 35 to 40 \\
\hline Inlet temperature & $(\mathrm{K})$ & 21.7 to 22.2 & 23.3 & 22.3 & 25.3 \\
\hline Time to clogging & (min) & 20 to 35 & 15 & 30 & 15 to 20 \\
\hline
\end{tabular}

*Orifice diameter for 1992 tests $=0.203 \mathrm{~mm}$ 


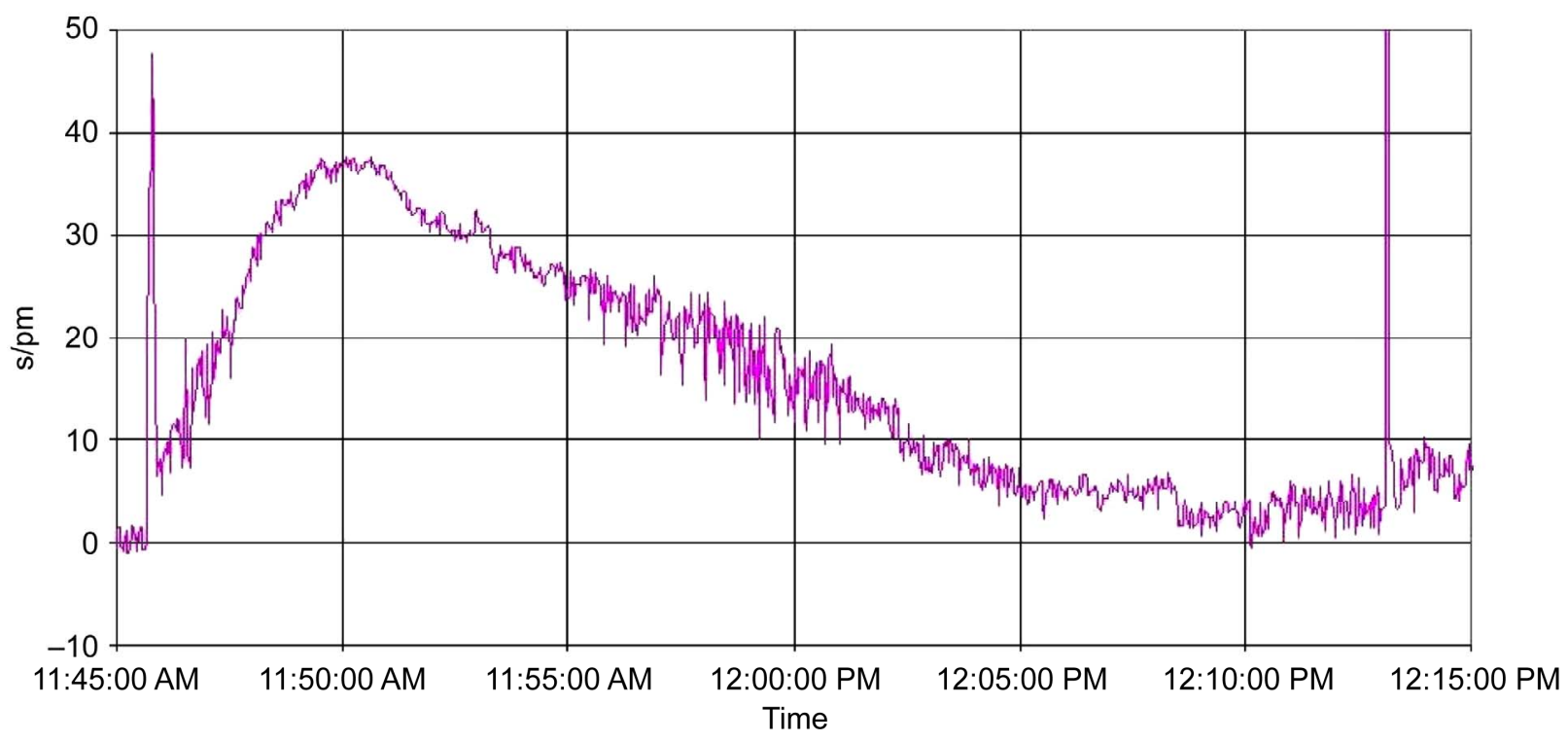

Figure 4.-Plot of $\mathrm{LH}_{2}$ flow rate versus time through $0.254 \mathrm{~mm}$ diameter orifice $\mathrm{T}$ (inlet) $=25 \mathrm{~K}, \mathrm{~T}$ (outlet) $=19.4 \mathrm{~K}$, Dewar pressure $=227.5 \mathrm{KPa}$.

Figure 4 shows a typical test run with flow starting at 37 slpm and decreasing to zero after 20 min. We observed similar behavior for the $0.178 \mathrm{~mm}$ orifice. For both orifices, the time it took for the orifice was on the same order of time (15 to $30 \mathrm{~min}$ ) as for the original 1992 tests.

Standard industrial grade $\mathrm{LH}_{2}$ was used in both the 1992 tests and the current test program. The advertised purity of hydrogen from the supplier does not specifically list neon as a contaminant. Table 5 lists the producers' purity specifications for industrial grade bulk liquid hydrogen. Note that neon is not listed specifically as a contaminant.

TABLE 5.-PRAXAIR BULK LIQUID HYDROGEN SPECIFICATIONS [Parts per billion volume]

\begin{tabular}{|c|c|}
\hline Contaminant or Purity & $\begin{array}{l}\text { Industrial grade bulk } \\
\text { liquid hydrogen }\end{array}$ \\
\hline Purity & 99.997 percent \\
\hline $\mathrm{H}_{2} \mathrm{O}$ & 5.000 \\
\hline $\mathrm{N}_{2}$ & 9.000 \\
\hline $\mathrm{CO}$ & ------------------ \\
\hline $\mathrm{THC}$ as $\mathrm{CH}_{4}$ & ------------------- \\
\hline $\mathrm{O}_{2}$ & 2.000 \\
\hline $\mathrm{CO}_{2}$ & ------------------- \\
\hline
\end{tabular}

A survey of gas producer literature shows that neon is typically not listed as an impurity. In fact, ultra high purity gas analyzers, capable of detecting impurities in the ppb range are not set up to detect neon. Calculations show that the presence of neon in less than one part per billion could result in clogging of the orifice. Since a very small quantity of neon is sufficient to induce clogging, and since its presence is not analyzed, it is quite possible that neon is present in the bulk liquid hydrogen, and is the cause of clogging. Results also indicate that the purity of industrial grade $\mathrm{LH}_{2}$ has not changed significantly over the past decade (if the neon indeed is the cause of clogging).

The possibility of neon contamination from the helium pressurant gas exists. However, again a review of helium supplier literature does not indicate neon as a contaminant, so it's presence in the helium supply cannot be ascertained. 


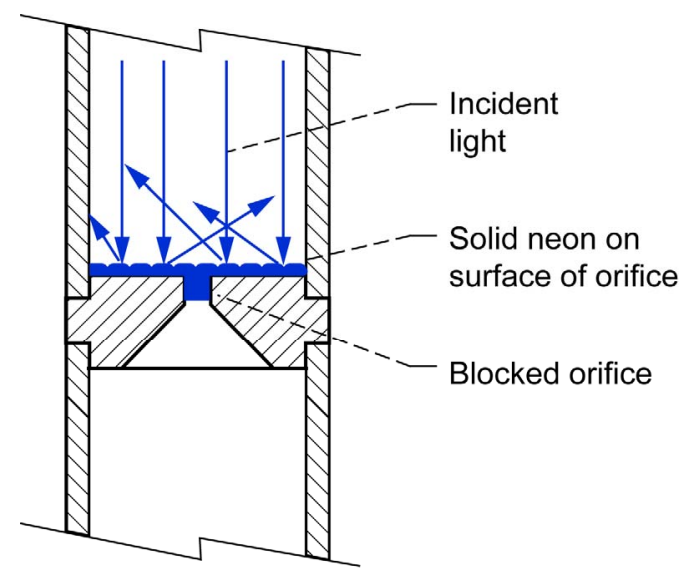

Figure 5.-Light scattering due to solid neon film on orifice.

Unfortunately, this program did not obtain conclusive visual evidence of the neon clogging phenomenon. Literally hundreds of digital pictures were taken of the orifice under varying flow conditions in an attempt to obtain a clear picture of the orifice while clogged. As mentioned previously, initial pictures were taken of the orifice prior to flowing $\mathrm{LH}_{2}$, and after the test run was complete. The orifice was clearly visible in these pictures, but when $\mathrm{LH}_{2}$ flowed through the orifice, the image was consistently clouded. A typical example is shown in Figure 7. Images 464, 466, and 506 all show the orifice clearly before and after the test run. Image 480 was taken approximately half-way through the test run. For the flow conditions, calculated Reynolds number indicated that the flow to the orifice was well within the laminar range, which should minimize the possibility of obscuring the view to the orifice due to turbulence in the fluid. Images taken during $\mathrm{LH}_{2}$ flow were consistently darker than no flow conditions. We have postulated several possible reasons for this phenomenon:

(1) Loss of camera focus

(2) Neon film on surface of orifice plate

(3) Extinction of light through two phase flow obscuration

\section{Loss of Camera Focus}

Loss of camera focus - The gaseous and liquid hydrogen have different refractive indices. This difference in refractive index will cause a difference in the geometrical distance to the image plane. So if the microscope is not refocused, then a well focused image of the orifice will blur and come out of focus as the gaseous hydrogen changes to liquid. The relationship between the optical distance, $O D$, geometrical distance, $d$, and refractive index, $n$, is:

$$
O D=n * d
$$

The gaseous hydrogen has an index of refraction that is approximately 1.01 and liquid hydrogen has an index of refraction that is approximately 1.1 (Ref. 4). The distance between the window and the orifice is approximately $9.8 \mathrm{~cm}$. The optical distance for the gaseous hydrogen is $9.898 \mathrm{~cm}$. The optical distance through the liquid hydrogen is $10.78 \mathrm{~cm}$. The difference in the optical distance is therefore about $1 \mathrm{~cm}$. This can explain why the image of the orifice was lost when the hydrogen changed phase but does not explain why the orifice could not be refocused, as the difference in OD is much less than the focus adjustment of the lens. 


\section{Neon Film on Surface of Orifice Plate}

If solid neon were deposited on the surface of the orifice plate, it is possible that the roughness of the solid neon surface could scatter incoming light instead of reflecting it back to the camera lens. We calculated the concentration of neon in the flow that could be deposited with a hydrogen flow of 40 slpm and orifice blockage occurring in 15 min (typical of these tests). A neon concentration of on the order of 1 ppm would be sufficient to coat the orifice $2 \mu \mathrm{m}$ thick. Surface roughness (peak to valley) would need to be on the order of several wavelengths of visible light to scatter incident light. Visible light has a wavelength of approximately $600 \mathrm{~nm}$, so the amount of neon theoretically deposited on the orifice surface would be sufficient to scatter incident light. Figure 5 show a notional picture of this possibility.

\section{Extinction of Light Through Two Phase Flow Obscuration}

Another possible reason for the image darkness is extinction of light due to light scattering off of bubbles of gaseous hydrogen. It is very likely that there was a significant amount of two phase hydrogen at these conditions. The bubbles of hydrogen would have a refractive index similar to gaseous hydrogen. The difference in refractive index between the bubbles and the liquid hydrogen will cause the incident light to scatter as is diagramed in Figure 6. This scattering of the light will significantly increase the attenuation of light through this medium and follows the exponential relationship shown in Equation (2):

$$
\Phi=\Phi_{0} * e^{-a x}
$$

Where $\Phi=$ power

$\alpha=$ absorption coefficient

$\mathrm{x}=$ distance through medium $\left(\mathrm{LH}_{2}\right)$

The density and size of the hydrogen bubbles is unknown and so the attenuation cannot be determined. However, this scattering of the incident and reflected light does explain both the darkening of the image and the inability to refocus the camera on the orifice.



Figure 6.-Light scattering due to two phase flow at orifice inlet. 


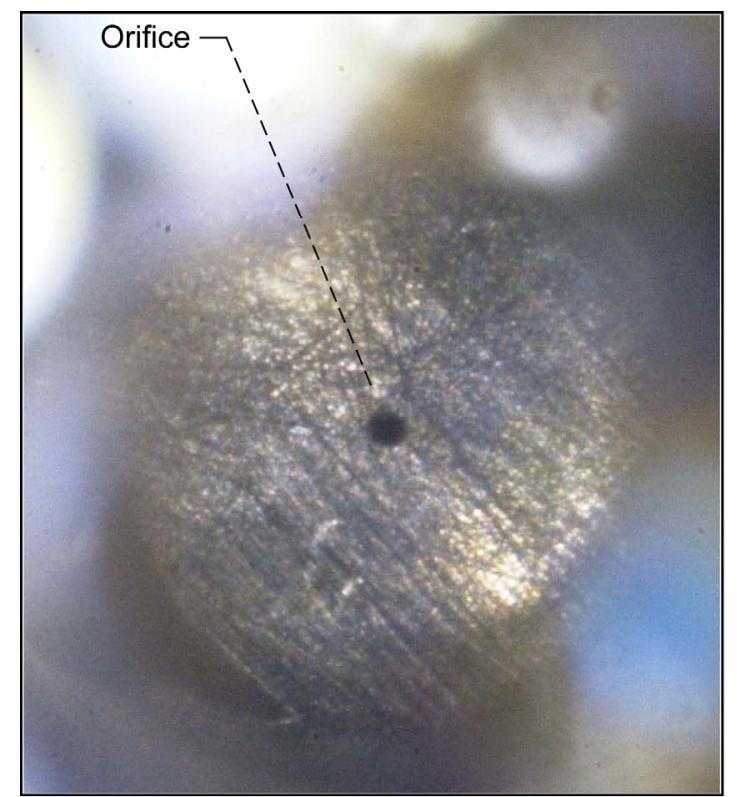

Image 464

No flow, $\mathrm{T}_{\text {inlet }}=255 \mathrm{~K}$

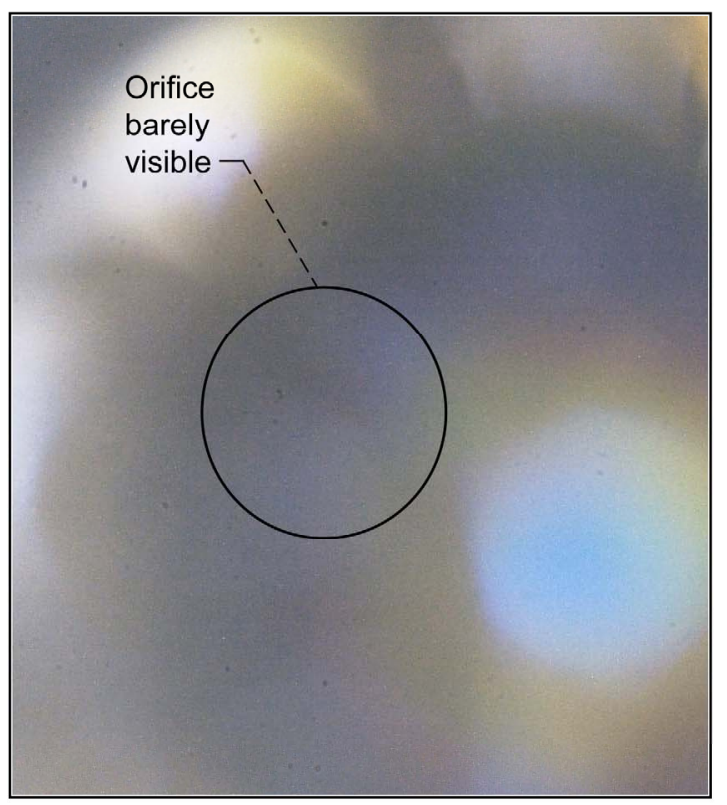

Image 480

Flow $=15 \mathrm{slpm}, \mathrm{T}_{\text {inlet }}=25.3 \mathrm{~K}$

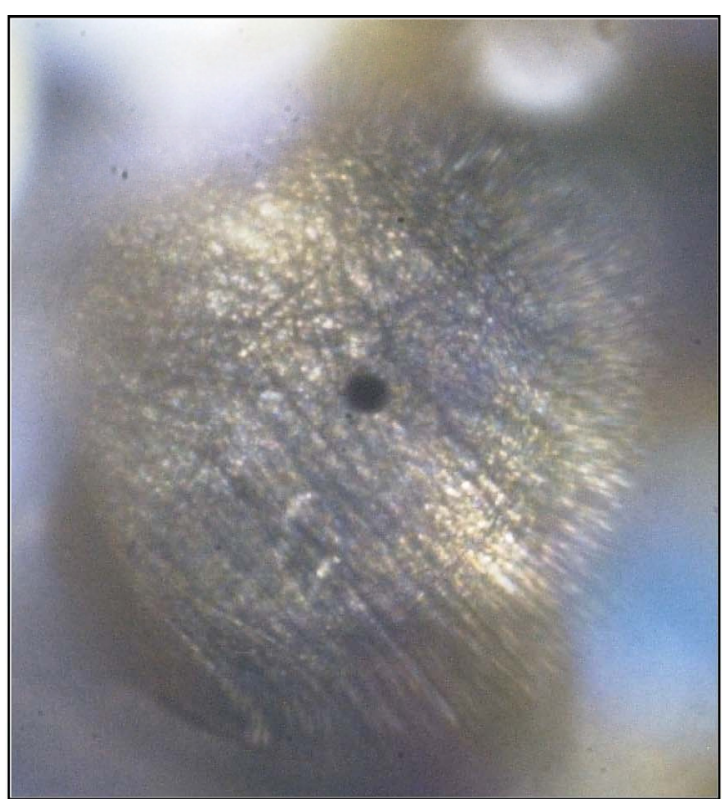

Image 466

No flow, $\mathrm{T}_{\text {inlet }}=22.8 \mathrm{~K}$

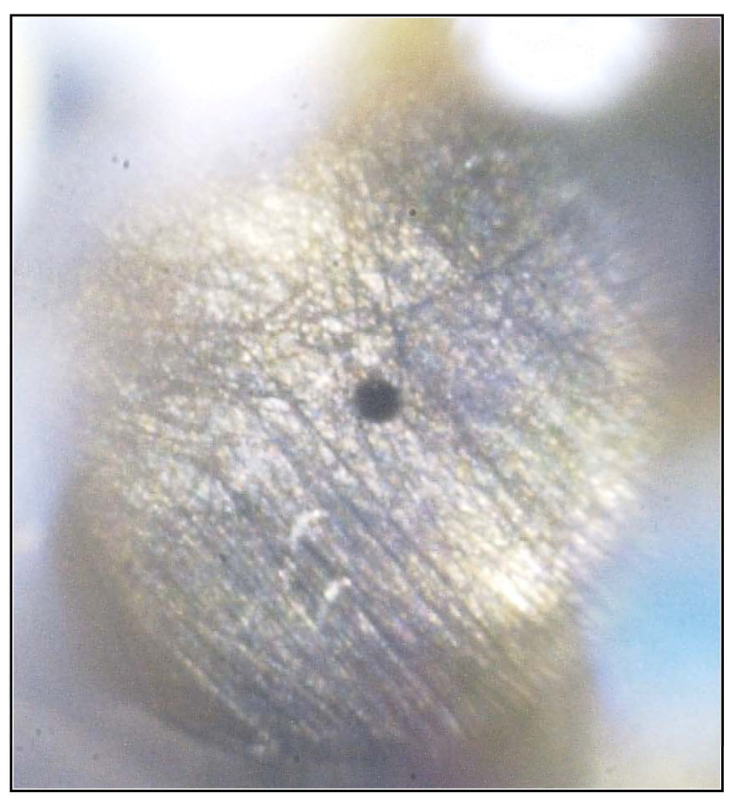

Image 506

No flow, $T_{\text {inlet }}=45 \mathrm{~K}$

Figure 7.- Images of $0.254 \mathrm{~mm}$ diameter orifice before, during and after $\mathrm{LH}_{2}$ flow. 


\section{Concluding Remarks}

The purpose of this test program was to definitively quantify the orifice clogging caused by accretion from neon contaminates in the $\mathrm{LH}_{2}$ flow stream, utilizing state of the art imaging technology. An additional goal was to repeat the 1992 tests to verify the clogging phenomenon.

Although we achieved the goal of repeating clogging, imaging results were less than satisfactory, very possibly due to insufficient illumination or light scattering. Of the options presented in this report, we believe that the image obscuration was most likely due to two phase flow upstream of the orifice.

Test results were comparable to previous observation; that is, the flow rate through the orifice decreased over time, indicating clogging in the orifice. Actual flow rates were lower than predicted, and also lower than for previous tests with similar size orifices. Low flow rates are probably due to two phase flow. The test could possibly be improved by decreasing the heat leak into the orifice assembly-either by fabricating test hardware from materials with lower heat leak, or submersing the entire assembly in the bulk liquid. The current configuration had design limitations based on focal length limits of the imaging equipment.

The significance of this effort has implications not only for propellant system design for existing cryogenic propellants, but also in evaluating design options for NASA's planned Exploration Vehicles propellant systems. Liquid oxygen $(\mathrm{LOX})$, liquid hydrogen $\left(\mathrm{LH}_{2}\right)$ and liquid methane $\left(\mathrm{LCH}_{4}\right)$ are options being considered for propellant systems. J-T devices have been identified as critical components for Thermodynamic Vent Systems (TVS) planned for future space exploration missions. These J-T devices may be used for $\mathrm{LOX}, \mathrm{LH}_{2}$, or $\mathrm{LCH}_{4}$ tank internal pressure control and supply manifolds to OMS-RCS thrusters.

\section{Future Work}

Future attempts at imaging might include improving the lighting. The current configuration used a ring of LED lights around the top of the sight tube. Perhaps more direct lighting using fiber optic light right at the orifice would improve results. Another possibility would be to use a different camera arrangement - possibly a boroscope type camera that could view the orifice from a much closer distance. Other possible configurations might utilize sheet laser to detect neon particles in the flow stream.

Testing is planned at NASA Glenn Research Center to characterize Visco Jets in LOX and $\mathrm{LCH}_{4}$. The purpose of these tests will be to determine if clogging occurs in Visco Jets with LOX or $\mathrm{LCH}_{4}$ via a similar mechanism. Attempts at imaging these devices are not currently planned. Testing will focus on mass spectrum analysis of the bulk cryogenic liquid and the Visco Jet outlet flow.

\section{References}

1. Papell S.S., Nyland T.W., Saiyed N.H., "Liquid Hydrogen Mass Flow Through a Multiple Orifice Joule-Thomson Device," AIAA-92-2881, 1992; NASA TM-105583.

2. Nyland T.W., "On the Clogging of Visco Jets and Orifices," NASA Lewis Research Center, Cleveland, OH, 1992, unpublished.

3. Jurns, J.M., Kudlac, M.T., "NASA Glenn Research Center Creek Road Complex-Cryogenic Testing Facilities," Cryogenics, vol. 46, 2006, pp. 98-104.

4. Diller, D.E., "Refractive Index of Gaseous and Liquid Hydrogen," The Journal of Chemical Physics, vol. 49, no. 7, October 1968, pp. 3096-3105. 


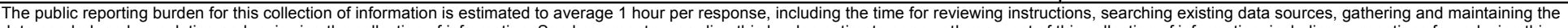



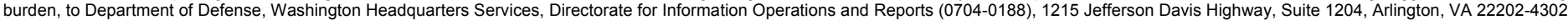


control number.

PLEASE DO NOT RETURN YOUR FORM TO THE ABOVE ADDRESS

\begin{tabular}{l|l|}
\hline $\begin{array}{l}\text { 1. REPORT DATE (DD-MM-YYYY) } \\
01-03-2009\end{array}$ & $\begin{array}{l}\text { 2. REPORT TYPE } \\
\text { Technical Memorandum }\end{array}$ \\
\hline
\end{tabular}

\section{TITLE AND SUBTITLE}

Clogging of Joule-Thomson Devices in Liquid Hydrogen Handling

\section{DATES COVERED (From - To) \\ 5a. CONTRACT NUMBER \\ NAS3-00145}

5b. GRANT NUMBER

5c. PROGRAM ELEMENT NUMBER

5d. PROJECT NUMBER

Jurns, John, M.; Lekki, John, D. 5e. TASK NUMBER

5f. WORK UNIT NUMBER

WBS 095240.04.06.03

8. PERFORMING ORGANIZATION

REPORT NUMBER

E-16661
7. PERFORMING ORGANIZATION NAME(S) AND A
National Aeronautics and Space Administration

John H. Glenn Research Center at Lewis Field

Cleveland, Ohio 44135-3191

\section{SPONSORING/MONITORING AGENCY NAME(S) AND ADDRESS(ES)}

National Aeronautics and Space Administration

Washington, DC 20546-0001

\section{SPONSORING/MONITORS ACRONYM(S) \\ NASA; AIAA}

\section{SPONSORING/MONITORING REPORT NUMBER \\ NASA/TM-2009-215495; AIAA-2006- 4877}

\section{DISTRIBUTION/AVAILABILITY STATEMENT}

Unclassified-Unlimited

Subject Categories: 20, 28, and 34

Available electronically at http://gltrs.grc.nasa.gov

This publication is available from the NASA Center for AeroSpace Information, 301-621-0390

\section{SUPPLEMENTARY NOTES}

\section{ABSTRACT}

Experiments conducted at the NASA Glenn Research Center indicate that Joule-Thomson devices become clogged when transferring liquid hydrogen $\left(\mathrm{LH}_{2}\right)$, operating at a temperature range from 20.5 to $24.4 \mathrm{~K}$. Blockage does not exist under all test conditions but is found to be sensitive to the inlet temperature of the $\mathrm{LH}_{2}$. At a subcooled inlet temperature of $20.5 \mathrm{~K}$ blockage consistently appears but is dissipated when the fluid temperature is raised above $24.5 \mathrm{~K}$. Clogging steadily reduced flow rate through the orifices, eventually resulting in complete blockage. This tendency poses a threat to spacecraft cryogenic propulsion systems that would utilize passive thermal control systems. We propose that this clogging is due to trace amounts of neon in the regular $\mathrm{LH}_{2}$ supply. Neon freezes at $24.5 \mathrm{~K}$ at one atmosphere pressure. It is postulated that between 20.5 and $24.5 \mathrm{~K}$, neon remains in a meta-stable, super-cooled liquid state. When impacting the face of an orifice, liquid neon droplets solidify and accumulate, blocking flow over time. The purpose of this test program was to definitively quantify the phenomena experimentally by obtaining direct visual evidence of orifice clogging by accretion from neon contaminates in the $\mathrm{LH}_{2}$ flow stream, utilizing state of the art imaging technology. Tests were conducted with $\mathrm{LH}_{2}$ flowing in the temperature range of 20.5 to $24.4 \mathrm{~K}$. Additional imaging was also done at $\mathrm{LH}_{2}$ temperatures with no flow to verify clear view through the orifice.

\section{SUBJECT TERMS}

Liquid hydrogen; Joule-Thomson effect; Fluid management; Cryogenic fluid storage

\begin{tabular}{|c|c|c|c|c|}
\hline 16. SECURI & ASSIFICATION & & 17. LIMITATION OF & 18. NUMBER \\
\hline $\begin{array}{l}\text { a. REPORT } \\
U\end{array}$ & $\begin{array}{l}\text { b. ABSTRACT } \\
U\end{array}$ & $\begin{array}{l}\text { c. THIS } \\
\text { PAGE } \\
\text { U }\end{array}$ & UU & $\begin{array}{c}\text { PAGES } \\
17\end{array}$ \\
\hline
\end{tabular}

19a. NAME OF RESPONSIBLE PERSON STI Help Desk (email:help@sti.nasa.gov) 19b. TELEPHONE NUMBER (include area code) 301-621-0390 

